\title{
Anatomical Studies on Graft Formation in Cashew (Anacardium occidentale L.)
}

\author{
1. Mahunu, G.K ${ }^{2}$. Adjei, P.Y. and ${ }^{3}$. Asante, A.K \\ ${ }^{1}$.Department Of Horticulture, University For Development Studies(UDS), Tamale \\ 2. Department of Horticulture KNUST, Kumasi \\ 3. Crops Research Institute (CSR) Fumesua.
}

Correspondence: P.Y. Adjei; Kwame Nkrumah University Of Science And Technology, (KNUST) Kumasi

Tel. 0244589813; e-mail py.adjei@yahoo.com

\begin{abstract}
The research studied the changes in the graft union with influence on graft success and subsequent performance until the $98^{\text {th }}$ day after initial side grafting of Anacardium occidentale rootstock seedlings. Thirty days after grafting, the necrotic layer and calli cells began enlarging between scion and stock. There was gradual disappearance of the necrotic layer, preceding callus formation and the fusion of the scion and stock at 60 day after grafting. Results at 98-days after grafting showed cambium linkage and a healed union edge. Unsuccessful grafts at 98-days after grafting showed a wide gap at the cortex of scion and stock. Graft union success is a key factor in successful graft-take and subsequent performance of grafted seedlings.
\end{abstract}

Key words: calli, Linkage. Union, Cortex.

\section{INTRODUCTION}

Propagation of plants played an important role in mankind since the beginning of civilization when man started to grow crops which were used for himself and his domestic animals some 10,000 years ago. As man progressed in civilization, people started to grow different plants that provided fibres, medication, ornamentals and beauty in addition to food crops. This also brought about several propagation abilities for a variety of plants (Hartmann and Kester, 1983).

Recently, vegetative propagation including grafting has generated interest among tree growers. It has been successful in producing fruit trees of small and manageable sizes which are precocious and productive. The basis of unity (in grafting and budding) between two parts of plants depends on mutual responsibility (Seferoğlu et al.,2004). Apart from tree or plant sizes, grafting produces planting stock that has suitable characteristics such as resistance to pest and diseases. Additionally, it provides an opportunity to clonally propagate selected trees with desirable tee phenotypes.

One of the important crops on the international market that has increasingly gained similar attention is cashew (Anacardium occidentale L.). In Ghana, cashew is an important non- traditional export commodity with raw nut export that increased from 7,212 metric tonnes in 2003 to 16,422 in 2006 (GSC, 2006). Cashew is mainly propagated by seed resulting in genetic variation of the crop (Dolgun et al., 2008). Grafting or budding however results in desirable phenotypes in fruits, seeds, etc. as already mentioned. The anatomical evaluation on graft sections gives the first information about compatibility or incompatibility of unions ( Kankaya et al., 1999). The aim of the study was therefore to facilitate an understanding into graft formation process for compatibility /incompatibility of cashew grafts through the changes in the graft union until the 98th day after initial side grafting.

\section{MATERIALS AND METHODS}

Cashew seedlings were grafted by using side grafting on rootstocks. Longitudinal and cross sections of $30 \mu \mathrm{m}$ diameter were taken in 30,60 and 98 days by using microtome for anatomical sectioning and examination. The sections were stained in safranine and later washed three times in distilled water. They were then dehydrated through different concentrations of alcohol starting with 5\% 30\% 50\% $75 \%$ and $100 \%$. Tissue paper was used to aid the drying of the specimen and clove oil was added. Subsequently, the sections were mounted onto slides using Canada balsam. The sections were oven dried 
at $60^{\circ} \mathrm{C}$ for 24 hours. Sections were then examined and photographed using photomicroscope fitted with $35 \mathrm{~mm}$ camera.

\section{RESULTS AND DISCUSSION}

The transverse section of the cashew seedlings revealed the following anatomical characteristics. The young cashew stem (transverse) was resinous and contained numerous parenchyma cells in the pith and cortex. The section also showed the epidermis at the outermost of the stem. The cambial zone consisted of an unbroken cylinder of cells arranged in radial files in the normal way. To the outside of the cambium were the phloem cells and to the inside of it were the immature and mature xylem cells (plate 1 ).

Several experiments have confirmed different models of graft union development with the entire process typically divided into stages. Soule (1971) in an earlier experiment indicated four important stages (pre-callus, callus, cambial bridge and the healed union) whiles Dolgun et al., (2008) reported three important steps ( callus formation, cambial differentiation and continuity and vascular tissues formation) in graft formation. The present anatomical study also revealed similar activities of graft union formation between the scion and stock that probably resulted in the graft success or failure observed. The observation, plate 2, showed that prior to callus formation, there was an occurrence of resin secretion onto the wound surface as an initial response of tissue damage during severing of the scion and rootstock. According to Asante and Barnett (1997), the resin secretion occurring within few minutes of knife wounding subsequently provided the sole cohesive force between the grafting partners in the first few days before a callus bonding is established.

The resin provided a temporary bond (cementing medium) between the two graft partners (Tiedeman, 1989) and by itself did not contribute to union formation. It eventually appeared as a dark staining or necrotic layer scattered between the grafted components (Dolgun et al., 2008) that could pose either as a "barrier" or "insulating layer" (Mendel, 1936). The excessive accumulation of necrotic layer could result to mechanical failure of union (Tiedeman, 1989; whereas Noel (1968), Cline and Neely (1983) mentioned that the presence of the necrotic layer at the wounded surfaces limited desiccation and death of the deeper tissues and reduced the entry of pathogens. Observation also indicated that the necrotic layer remained at the interface until callus was subsequently formed and completely filled the graft interface by $30^{\text {th }}$ day after grafting (plate 3 ). Most of the callus cells enlarged and divided mostly in the stock (Dolgun et al., 2008). Asante and Barnett (1997) mentioned that callus formation is crucial to the survival of the scion and the rapid physical contact of opposing callus cells intermingling and inferlocking, filling up the spaces between the scion and rootstock, provides a bridge for the transport of water and nutrients (Miller, 1991). Copes (1969) stated that this callus bridge develop most often in the cortex and non-functional phloem area where contact layers were continuous with the ray and phloem parenchyma being the chief contributors to its growth.

However, failure of grafts will occur due to water stress when scions are unable to receive water from the rootstocks before the graft union is formed (Barnett and weatherhead, 1989; Mergen, 1954). The phenomenon indicates the response of the scion to corresponding increases in transpiration and temperature (Beeson and Proebsting, 1988). At this stage the continuous formation and intermingling callus caused the gradual disappearance of the necrotic layer between the two graft components. A greater proportion of the necrotic layer by the $60^{\text {th }}$ day had been eliminated and the grafting line became less distinct (Dolgun et al; 2008); (plate 4). Dolgun et al, (2008) and Tekintas and Dolgun (1996) also reported that between $45-60$ days after grafting callus tissues had filled all spaces and cambial continuity were observed clearly.

Alongside were also observations of vascular tissues produced by newly formed cambium. However, the establishment of the cambial continuity is considered vital for the production of vascular tissues in ensuring a successful completion of the grafting process. By the $98^{\text {th }}$ day, the union process appeared transformed as a common cambium ring was formed between the rootstock and scion (plate 5) but this study could not confirm clearly the complete formation of vascular tissues. This is due to the fact that reports concerning vascular tissue connections vary. Seferoğlu et al. (2004), for example indicated that a period of $6-12$ months was necessary to observe completion of vascular connection between the scion/bud and rootstock. Other reports noted vascular connection in $6-8$ weeks after grafting (Soule, 1971; Moore, 1981; 1982 and 1993). In citrus, Tekintas (1991) reported that cambial continuity occurred in 45 (forty five) days after grafting. Several literature reports indicate that vascular differentiation begin after establishment of cambial continuity and 
the strong connection occur in a short time in a compatible graft. This occurrence (Continuity or Connectivity) is considered the last stage of the successful grafting with an established and functional vascular connection that provides water and nutrient flow from rootstock to scion/bud (Turkoglu, 1990; Unal and Ozcagiran, 1986; Moore, 1983, 1984; Tekintas, 1988; Watanabe and Nakazatomi 1990; Unal, 1992; Asante and Barnett, 1997). Hartmann et al. (1997), reported that for a scion to successfully resume its growth, the vascular connection has to be established and in addition the scion must have a meristematic region (bud) to resume shoot growth and eventually to supply photosynthates to the root system. Unsuccessful grafts showed gaps at the periphery or cortex of the graft components (plate 6). Several factors and conditions have been attributed to failure of graft formation. Amongst others, the change of the temperature and relative moisture especially during and after grafting directly affects the development of a good graft union (Balta, et al., 1996; Tekintas, 1988) and high day temperatures with warm nights are stressful for successful union (Hinesley, 1981). Shade improved the success of grafts during high day temperatures and decreased ambient air temperatures, and thus improved graft success (Frey, 2009). Apart from the fact that some species form large amounts of callus than others the species that form callus quickly are likely to unite if properly grafted and those that form callus slowly are less likely to unite. However, it is important to make a definite effort to place scion on the stock, to have the two cambium layers match at least on one side to prevent a delay of ultimate union (Dolgun et al.; 2008).

\section{CONCLUSION:}

Results and observation from the experiment indicate adequate and early callus formation is important for initial scion survival and subsequent formation of the cambium and vascular tissues. Again the proper matching of the two components contributes significantly to graft union success.

\section{ACKNOWLEDGEMENT:}

The authors acknowledge the Departments of Horticulture (KNUST) and Crops Research Institute (CRI) for their major contributions in terms of materials and Equipments.

\section{REFERENCES}

Asante, A.K. and Barnett, J.R. (1997). Graft union formation in mango (Mangifera indica L.) Journal of hort sci. 72; 781-90
Barnett, J. R. and Weatherhead, I. (1988). Graft formation in a sifka spruce, a scanning electron microscope study. Ann. Bot. 61: 577-581

Beeson, R.C and Proebsting, W.M. (1988). Relationship between transpiration and water potential in grafted scion of picea. Physiol plant. 74:481-486.

Balta, F.; Kazankaya, A. and Tekintas, F.E. (1996). Anatomical and histological observation prior to transplanting on omega grafts(J. regia L.) exposed to the controlled conditions. Symp.on hazelnut and other nut crops, OMU Agric.Fac., samsun, pp.343-352.

Cline, M. N. and Neely, D. (1983). The histology and histochemistry of the wound healing processing geranium cuttings. J .Amer soc.hort. sci.108

Copes, D.L. (1969). Graft union formation in Douglas fir. Amer. J. Bot. 56.285-289.

Dolgun. O.; Tekintas, F.E. and Ertan, E. (2008). A histological investigation on graft formation of some Nectarine cultivars grafted on pixy rootstock. World Journal of Agriculture Sciences 4(5): 565 -568.

Frey, H.H. (2009). Factors affecting graft success and early growth of fraser fir (Abies fraseri) Msc. Thesis. Forestry, Raleigh, North Carolina, 20p

Ghana Shippers council (2006). In a report on cashew nut marketing: Major Issues. Ghana cashew products document, Accra. Ghana.

Hartmann, H.T. and Kester, D.E.( 1983). Plant propagation, principles and practices, prentice Hall, New Jersey, pp 727.

Hartmann, H.T.; Kester, D.E.; Davies, F.T and Geneve, R.L. (1997). Plant propagation, principles and practices, printice Hall, New Jersey, p.346.

Hinesley, L.E. (1981). Initial growth of fraser fir seedlings at different day/ night temperature. For. Sci.27:545-550.

Kankaya, A., Ozyiğit, S., Tekintas, S. E. and Seferoğlu, G. (1999). The compatibility of some plum and Apricot cultivars with pisy rootstock IV, National Horticultural Symposium p. 295-299, Ankara, Turkey

Mergen, F. (1954). Anatomical study of slash pine graft unions. Quarterly journal of the Florida Academy of Science, 17 (4), 237-45.

Moore, R. (1981). Graft compatibility/ incompatibility in higher plants. What's new in plant physiology? Vol. 12 (4) : 13-16

Moore, R. (1982). Further evidence for cell wall deposition during graft formation. Ann. Bot., 50:599-604

Moore, R. (1983). Studies of vegetative compatibility in higher plants IV. The development of tensile strength in a compatible and an incompatible graft. Amer. J. Bot., 70 (2) : 226-231. 
Moore, R. (1984). Model for graft compatibility/ incompatibility in higher plants. Amer. J. Bot., 71(5) : 752-758

Miller, H. (1991). The effects of Heat on graft union formation in Dormant sitka spruce (Picea sitchensis (Bong, Carr.) PhD. Thesis, University of Reading.

Mendel, K. (1936). The anatomy and Histology of the budunion in citrus (contribution from the Division of Horticultural physiology and Genetics, Jewish Agency for Palestine, Agricultural Exp. Station, Rehovot). Palestine Journal of Botany. 1 (2), 13-46

Noel, A. R. A. (1968). Callus formation and differentiation at an exposed cambial surface. Ann. Bot. 32 : 347-359

Seferoğlu, G., Tekintas, F. E. and Ozyiğit, S. (2004). Determination of grafting union success in 0900 Ziraat and Starks Gold Cherry cultivars on Gisela 5 and SL 64 rootstocks. Pak. J. Bot., 36 (4) : 811-816.

Soule, J. (1971). Anatomy of the bud union in mango (Mangifera indica L.) J. Amer. Soc. Hort. Sci., 96 (3): 380-383.

Tiedemann, R. (1989). Graft union development and symplastic phloem contact in the heterograft Cucumis sativus on cucurbita ficifolia. J. plant physiol. 134, 427 -440 .
Tekintas, F. E, and Dolgun, O. (1996). An investigation on compatibility in some peach and Nectarin cultivars grafted on Almond seedling, 100. Y21 univ. J. Fac. Agric., 6 (1): 51-54.

Tekintas, F. E. (1991). An anatomical and histological investigation on graft formation in citrus species and varieties grafted on different rootstocks, 100. Yil univ. J. Fac. Agric, Van, Turkey, 1(2) : 68-81.

Tekintas, F. E. (1988). Investigations on graft union in Walnut (Juglans regia L.) and regard to problems. PhD Thesis, Ege univ. Agricultural Faculty, P 105.

Turkoglu, N. (1990). An investigation on different grafting Techniques and effects of Hormones on rooting in Rosa canina in van ecological conditions. Master Thesis, 100. Yil univ. Institute of science and Technology, Van, Turkey.

Unal, A. and Ozcagiran, R. (1986). Graft Formation in Budding, Doga. Turk. J. Agric. Forest, 10 (3): 399-407.

Unal, A. (1992). An investigation on Anatomical characteristics of grafting in Almond, Plum and Apricot grafted on Apricot rootstocks. National Horticultural Congress, Izmir, Turkey, pp 41-45.

Watanabe, S. and Nakazatomi, N. (1990). Formation of the graft union in apple T- budding, Bull. Yamagata Univ., Agricultural sci., 11 (1): 149-153. 